\title{
Grain size selection in case building by the mountain cased-caddisfly species Potamophylax latipennis (Curtis, 1834): a trade-off between building time and energetic costs
}

\author{
Quim De Gispert1,*, Guilherme Alfenas² and Núria Bonada ${ }^{1}$ \\ ${ }^{1}$ Grup de Recerca Freshwater Ecology and Management (FEM), Departament de Biologia Evolutiva, Ecologia i \\ Ciències Ambientals, Institut de Recerca de la Biodiversitat (IRBio), Facultat de Biologia, Universitat de \\ Barcelona (UB), Diagonal 643, 08028 Barcelona, Catalonia, Spain. \\ 2 Laboratorio de Limnologia - Universidade Federal do Rio de Janeiro, Rio de Janeiro, Brasil. \\ * Corresponding author: quim.dgp@gmail.com
}

Received: 20/03/17

Accepted: 14/06/17

\begin{abstract}
Grain size selection in case building by the mountain cased-caddisfly species Potamophylax latipennis (Curtis, 1834): a trade-off between building time and energetic costs

Many caddisfly larvae build cases to facilitate breathing, provide physical protection, reduce predation, avoid becoming drift, or prolong survival during drying conditions. Case building also requires significant energetic costs related to grain searching and silk production, which may involve a trade-off with the size of grain used. Thus, building cases with large grain sizes would require less time (i.e., a trait related to survival) but higher silk production (i.e., a trait related to fecundity), whereas building with small grain sizes would show the contrary pattern. Grain size selection, time spent, and energetic costs related to case building were assessed on the Limnephilid species Potamophylax latipennis. Laboratory experiments were conducted in order to force individuals to build using seven different experimental conditions with varying grain size availability. Results showed a trade-off between time and energetic costs. $P$. latipennis prioritized building cases with grain sizes that provide a faster building although they used larger amounts of silk. In addition, when individuals were first forced to build a case using a unfamiliar substrate and then placed in the native (i.e. from the river) substrate, most unfamiliar grains where replaced by native ones, even though it represented an extra cost for the individuals. Despite the high energetic costs of building cases in Trichoptera and their potential implications for reproductive traits in the adult stage, larvae individual survival was prioritized.
\end{abstract}

Key words: case-building, Limnephilidae, trade-off, silk-production, survival, Trichoptera

\section{RESUMEN}

Selección del tamaño de partícula en la construcción del estuche de la especie de tricóptero de montaña Potamophylax latipennis (Curtis, 1834): un compromiso entre el tiempo de construcción y los costes energéticos)

Muchas especies de tricópteros construyen estuches para facilitar la respiración, protegerse, reducir la depredación, evitar la deriva, o prolongar la supervivencia en condiciones de sequía. Sin embargo, la construcción de estos estuches requiere importantes costes energéticos relacionados con la búsqueda de partículas y la producción de seda, que pueden implicar un compromiso con el tamaño de la partícula usado. De esta forma, la construcción de estuches con partículas de tamaño grande requeriría menos tiempo (i.e., un rasgo relacionado con la supervivencia), pero una mayor producción de seda (i.e., un rasgo relacionado con la fecundidad), mientras que la construcción con partículas de tamaño pequeño mostraría el patrón contrario. Evaluamos la selección del tamaño de la partícula, el tiempo de construcción, y los costes energéticos vinculados a la producción de seda en la especie de limnefílido Potamophylax latipennis. Se llevaron a cabo experimentos de laboratorio para obligar a los individuos a reconstruir el estuche en 7 condiciones experimentales diferentes en las que se variaba el tamaño de la partícula disponible. Los resultados mostraron un compromiso entre el tiempo y los costes energéticos. P. latipennis priorizó la construcción de estuches con partículas de tamaño grande que proporcionan una construcción más rápida a pesar de tener 
un mayor gasto de seda. Además, cuando los individuos fueron forzados a reconstruir dos veces, primero con un sustrato no habitual y después con sustrato nativo (i.e., del río), remplazaron las partículas de sustrato no habitual por nativas, aunque ello representara un coste adicional para los individuos. A pesar de los altos costes energéticos que supone la construcción de estuches en tricópteros y sus posibles implicaciones en la reproducción de los adultos, P. latipennis priorizó la supervivencia individual de la larva.

Palabras clave: construcción de estuches, Limnephilidae, compromiso, producción de seda, supervivencia, Trichoptera

\section{INTRODUCTION}

Many organisms build structures, such as nets or cases, to protect themselves or to assist in feeding or reproduction (Dudgeon, 1990; Bucheli et al., 2002; Statzner et al., 2005; Chaboo et al., 2008). These structures are built using material found in the vicinity, self-secreted material, or both types. In the freshwater world, Trichoptera are the underwater architects. Despite the fact that case building is not universal in this group of insects, most families of Trichoptera build cases of a wide variety of sizes, shapes, and materials, including self-produced silk, mineral grains, detritus, or live organisms such as algae or molluscs (Wiggins, 2004). The benefits of building cases in Trichoptera have been discussed extensively in the literature and have mainly been associated to increased survival. Cases assist in respiration by facilitating unidirectional flow when larvae move their abdomens, provide physical protection, serve as camouflage against predators, give extra weight to the individual to avoid becoming drift, or prolong survival during drying conditions (Hansell, 1974; Otto \& Svensson, 1980; Otto, 1982; Williams, 1987; Dudgeon, 1990; Nislow \& Molles, 1993; Otto \& Johansson, 1995; Wiggins, 1996; Zamora-Muñoz \& Svensson, 1996; Wissinger et al., 2004, 2006).

Case building and repair has been analysed from various points of view, including animal behaviour, evolutionary biology, or basic life history characteristics (e.g., Houghton \& Stewart, 1998; Gupta \& Stewart, 2000; Norwood \& Stewart, 2002; Mendez \& Resh, 2008). Different studies have demonstrated that larvae can use a wide range of materials when the most favoured material for building cases is not accessible (Gorter, 1931; Gaino et al., 2002). For example, Gaino et al. (2002) showed that larvae that prefer travertine for case building switch to quartzite if the former is unavailable. In addition, the type of material used can vary along the ontogeny of a particular species or with the presence of predators or other environmental conditions (Boyero et al., 2006). Other aspects besides the type of material, such as the size of the grain or the past experience, are also important during case building. For example, species that build mineral cases can switch to larger of smaller grain sizes when the material of the preferred size is unavailable grain size (Hanna, 1961; Tolkamp, 1980), and many Trichoptera species exhibit grain size selection depending on past experience (i.e., allowing the insect to evaluate the quality of a particle in relation to a previous one) (Nepomnyaschikh, 1992). All this suggests that species can be flexible when choosing their building material.

Case building requires energy. Besides the energy spent while collecting the building material, there is also a direct cost of silk production by the larval labial glands (Stevens et al., 1999, 2000). Especially in the case of the Limnephilidae, the costs associated with silk production are very high because large amounts of silk are produced, not only to glue grains together but also to cover the inner lining of the case in order to obtain a smooth surface. For example, Otto (1974) found that the cost of silk production for case construction during the last instar of Potamophylax cingulatus might represent $12 \%$ of the energy expenditure. In addition, building also represents significant losses of larval protein (e.g., of about 35 \% in Limnephilus rhombicus; Mondy et al., 2012), and might have an impact on the fitness of the adults, despite the fact that costs for case building can be mitigated by the reallocation of resources during metamorphosis (Jannot et al., 2007). In many insects adult structures depend entirely on larval resources (Boggs, 1981). In Trichoptera, costs for case building have been linked to a reduction of the thoracic 
mass and the wing length, or to the incapacity to synthesise yolk and maturing eggs (Wheeler, 1996; Stevens et al., 2000; McKie, 2004). Therefore, silk production is ultimately associated with the fecundity traits of the adult phase. Because of these important energetic costs, repair behaviour may be more beneficial than building the entire case for larvae (Kwong et al., 2011).

The aim of this study was to investigate case building behaviour and repair in the Limnephilidae species Potamophylax latipennis, focusing on two aspects: grain size selection and energetic costs. Giving that grain selection behaviour within a genus or species might respond to the availability of material and the associated energetic costs. Therefore, our first hypothesis is that grain size selection during the building process in $P$. latipennis should reach an optimal balance between time for building (i.e., protection which can have consequences on several survival traits, see above; e.g., Hansell, 1974; Otto \& Svensson, 1980; Nislow \& Molles, 1993) and silk used (i.e.,

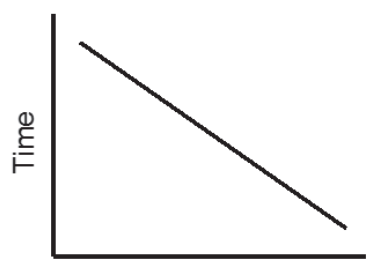

Grain size
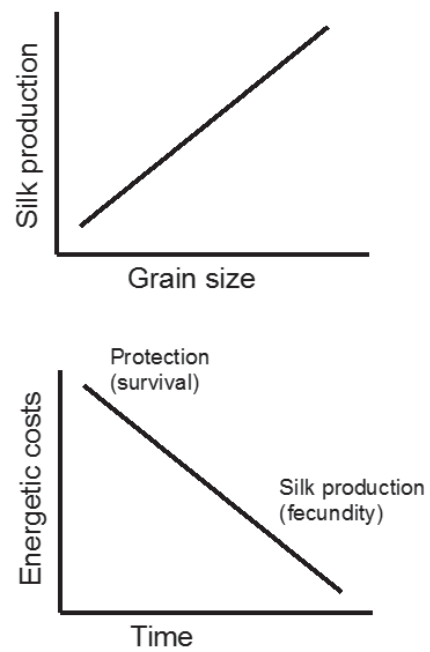

Figure 1. Main hypotheses related to the first experiment and tested in this study. Hipótesis principales relacionadas con el primer experimento y testadas en este estudio. energetic costs with potential consequences on several fecundity traits, see above; Wheeler, 1996; Stevens et al., 1999, 2000; McKie 2004, Jannot et al., 2007). Building cases with a higher proportion of larger grain sizes than the original cases may require less time to build the case and provide a faster protection of larvae, but may imply a higher silk production to glue these large particles together (i.e., they are heavier and thus more difficult to fix). In contrast, building cases with smaller proportion of grain sizes than the original cases may require more time although gluing these small particles together may require less silk production (Fig. 1). However, grain selection in Trichoptera has also been related to the smoothness of the grain or its chemical composition (Okano \& Kikuchi, 2009; Okano et al., 2010, 2012). Additionally, most Trichoptera species tend to partially or completely repair the case after eliminating damaged or less-suitable parts (Kwong et al., 2011), which may result in an extra cost. Therefore, our second main hypothesis is that larvae of $P$. latipennis will build cases regardless of the type of available material (i.e., native or unfamiliar) to prioritize survival, but when building with unfamiliar material, individuals will repair their cases using native material, indicating a preference for the native material independently of the costs linked to building.

\section{METHODS}

\section{Species description and sampling}

The species $P$. latipennis inhabits high mountain rivers with cold waters and shallow waters of mountain lakes. Larvae are shredders, feeding mainly on leaves and stems, and can be very abundant in well-oxygenated pools (Graf et al., 2008). Pupae aggregate under cobbles located in riffles to facilitate oxygen uptake (Hynes, 1970; Newbury \& Gaboury, 1993). The species has a univoltine cycle with a flying period from summer to autumn (Graf et al., 2008) and a Palearctic distribution. In the Iberian Peninsula, where this study was carried out, $P$. latipennis has been mainly found in mountain rivers in the northern half region (González et al., 1992).

The specimens were collected in a pool of the 
Ritort River in the locality of Espinavell (Girona, North-East of Spain) at $1184 \mathrm{~m}$ a.s.l. (42 $\left.22^{\prime} 31.43^{\prime \prime} \mathrm{N}, 2^{\circ} 23^{\prime} 52.33^{\prime \prime} \mathrm{E}\right)$. This river is a tributary of the Ter River in its left side and has a siliceous geology mainly composed of schist with limestone, dolomite, and marble. Riparian vegetation is dense and dominated by Alnus glutinosa and Corylus avellana. Substrate is mainly composed of rocks, cobbles and pebbles, with sand present in the most lentic areas.

Individuals of the last instar (i.e., with the case completely composed by mineral grains; Vieira-Lanero, 2000) were collected and brought alive to the laboratory where the experiments were conducted. To recreate the original native substrate, a large sample of sand, gravels, pebbles, and little branches were collected in the same pool where individuals were sampled. Several water tanks were also collected from a nearby fountain to have water with similar characteristics. Finally, dry leaves from A. glutinosa and $C$. avellana were collected from the riverbanks to feed the larvae.

Larvae were acclimatized during one week in an aquarium that recreated the original river conditions, providing food ab libitum. The aquarium had a water recirculation system with an active carbon filter that cleaned and oxygenated the water continuously, and a refrigeration system that maintained the water temperature at $6.6{ }^{\circ} \mathrm{C}$, simulating river conditions.

\section{Experiment 1: Grain size selection}

During May 2013, a total of 35 larvae were randomly selected from the aquarium and removed from their cases. The original cases were kept in dry conditions while larvae were individually put into circular covered cages of a diameter of ca. $10 \mathrm{~cm}$, made of a plastic net of ca. $1 \mathrm{~mm}$ of mesh size and filled with combinations of three different grain sizes of native substrate (i.e., from the river where larvae were collected): small (0.5-1 mm), medium (>1-1.5 mm), and large ( $>1.5-2 \mathrm{~mm})$. These three types of substrate were obtained by sieving sand from the pool where we collected the larvae through different sieves and washing them vigorously. The
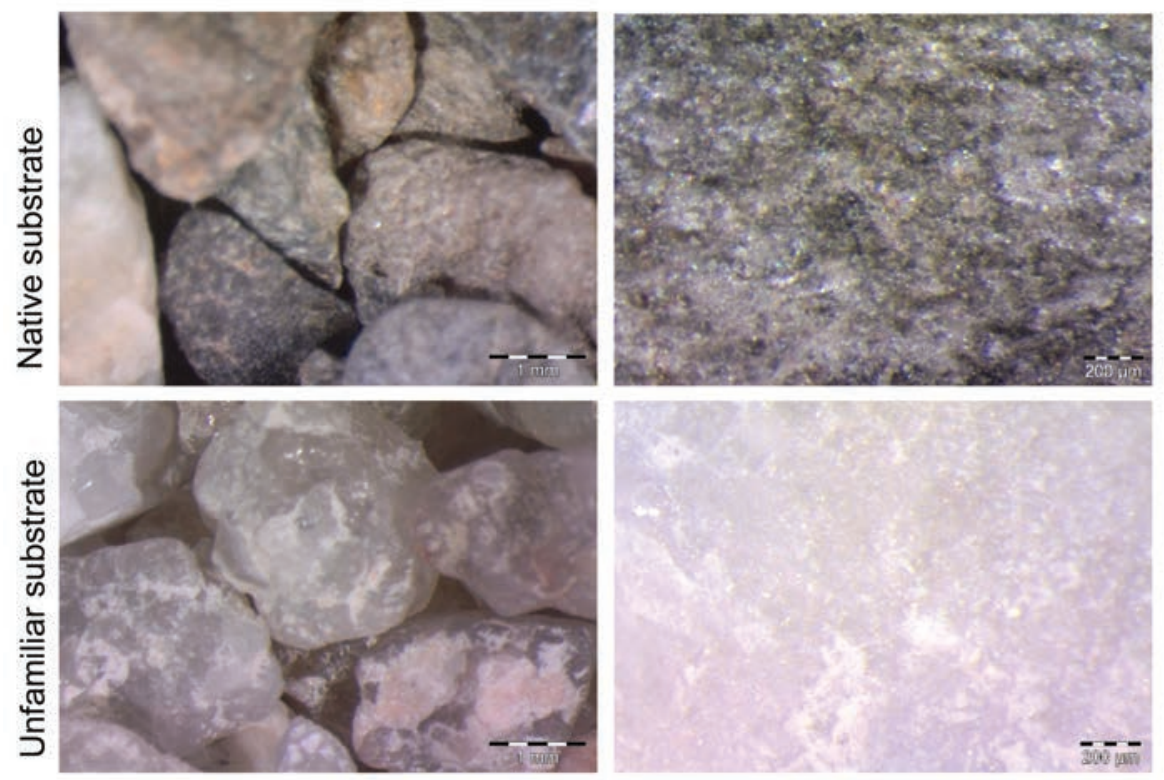

Figure 2. View of the native (i.e., from the river where larvae were collected) and unfamiliar (quartz from Jardiland (C) substrates used in the second experiment. A general (left) and detailed (right) view is provided. Visión del substrato nativo (del río donde se recolectaron las larvas) y no habitual (cuarzo de Jardiland (C) utilizados en el segundo experimento. Se aporta un visión general (izquierda) y detallada (derecho). 
substrate covered the whole cage and had a thickness of ca. $5 \mathrm{~mm}$. We set up seven experimental conditions that included different proportions of the three grain sizes: three different cages with $100 \%$ of small (S), medium (M), and large (L) grain sizes, respectively; three cages included only two grain sizes with $50 \%$ of weight each (LM for large and medium, MS for medium and small, and LS for large and small); and one cage had the three grain sizes, respectively, with $33 \%$ of weight each (LMS for large, medium, and small). Each experimental condition was replicated five times. The combination of grain sizes in each experiment was done by weight instead of by number of particles to make all grain sizes equally available during case building. Therefore, all results are expressed in weight instead of number of particles.

Each experimental condition had only one larva. Given that we initially observed that larvae were almost unable to build a case with cages filled only with sand, we placed two overlapping pebbles to facilitate the building and to give protection to larvae. The cages were covered with a plastic net to avoid larvae escaping. The time, since the beginning of the experiment until the whole case was built and the larvae freely moved through the cage was recorded. As the experiment last for $11 \mathrm{~h}$, those larvae that did not finish the building during this time, had a value of $11 \mathrm{~h}$ for the time variable. All larvae were preserved in alcohol and removed from the rebuilt cases. The original and the rebuilt cases were dried in a stove at $60{ }^{\circ} \mathrm{C}$ and weighed. Subsequently, cases were burned in a muffle at $400^{\circ} \mathrm{C}$ for six hours to burn the silk used, and weighed again. The weight difference between the dry and muffled cases divided by the weight of the dry cases was used to calculate the silk expenditure in the original and the rebuilt cases. Finally, the grains used in the original and the rebuilt cases were sieved through different sieves to determine the proportion of the weight of L, M, and S particles used.

\section{Experiment 2: Case repairing}

During June 2014, a total of 92 larvae were removed from their cases, and forced to build over one of three different experimental condi- tions: 1) using their native substrate (including L, $\mathrm{M}$, and $\mathrm{S}$ grains) $(\mathrm{n}=30) ; 2)$ using an unfamiliar substrate of $100 \%$ quartz (including L, M, and S) designed for aquariums by Jardiland $\odot(n=30)$; and 3) using first the unfamiliar substrate and, once the case was completed, moving them over the native substrate $(\mathrm{n}=32)$ (both also including $\mathrm{L}$, $\mathrm{M}$, and S). In this last experimental condition larvae were moved from the unfamiliar to the native substrate to assess if individuals repaired their cases during the following 48 hours (i.e., they changed the unfamiliar grains to native ones). The unfamiliar substrate was vigorously washed before the experiment to remove any powder that could inhibit case building. This substrate had a visible smoother surface but a higher waviness (larger scale undulation which contributes to particle shape) than the native substrate when analysed under a stereoscope (Fig. 2). All larvae were preserved in alcohol and removed from the rebuilt cases. As in the Experiment 1 , the original and the rebuilt cases were dried in the stove and weighed before being burned in a muffle at $400{ }^{\circ} \mathrm{C}$ for six hours to

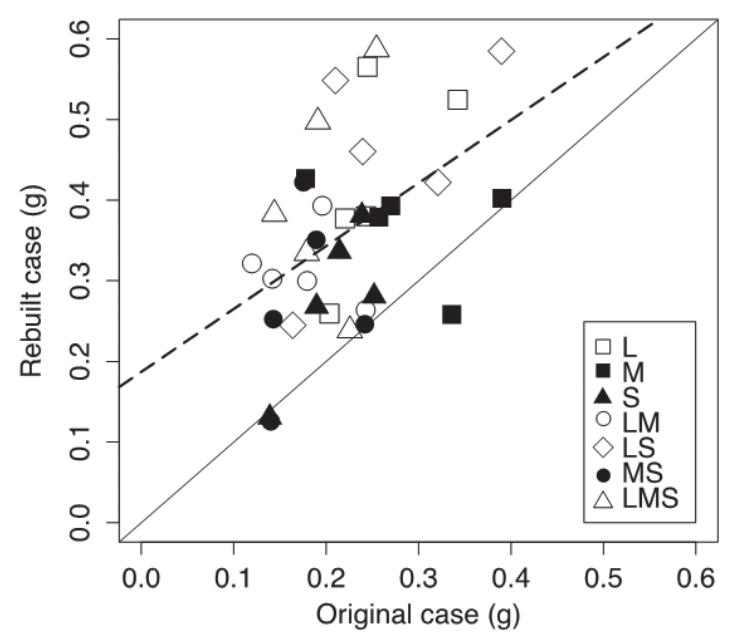

Figure 3. Amount of grains used by each individual in the original and the rebuilt cases. The solid line shows the $\mathrm{x}=\mathrm{y}$ relationship, whereas the dashed line is a linear model fit showing that there is a significant and positive relationship between both variables. Cantidad de partículas utilizadas por cada individuo en los estuches originales y reconstruidos. La línea continua muestra la relación $x=y$, mientras que la línea discontinua muestra el modelo lineal ajustado según el cual hay una relación positiva y significativa entre las dos variables. 
remove the silk used, and weighed again. The weight difference between the dry and muffled cases divided by the weight of the dry cases was used to calculate the silk expenditure in the original and the rebuilt/repaired cases.

\section{Data analysis}

Data were analyzed using descriptive statistics and regression analyses. Linear models were applied when comparing pairs of continuous variables (time and weight). The non-parametric Mann-Whitney-Wilcoxon tests were used for comparisons among grain sizes used (in weight) and experimental conditions. This test was preferred over other non-parametric tests because it allowed pairwise comparisons that are
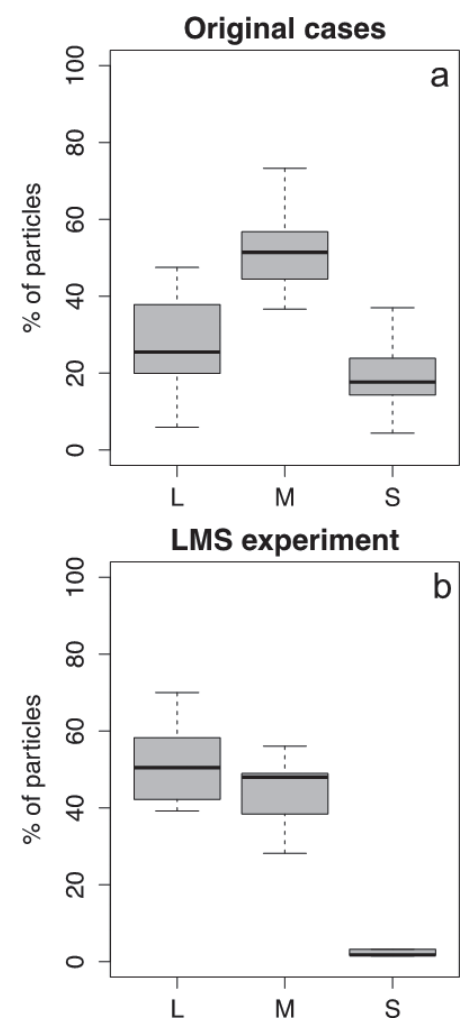

Figure 4. Boxplots showing the weight percentage of each grain size used in the original (a) and in the LMS (large, medium, and small) experimental condition (b). ( $\mathrm{L}=$ large grain size, $\mathrm{M}=$ medium, $\mathrm{S}=$ small). Diagramas de cajas mostrando el porcentaje en peso de cada tamaño de partícula utilizada en los estuches original y la condición experimental LMS (grande, mediana, pequeña). ( $L=$ tamaño de partícula grande, $M=$ mediana, $S=$ pequeña). corrected for multiple testing. When tests included more than two comparisons or pairwise comparisons were not needed, the non-parametric Kruskal-Wallis test was used. All analyses were computed using R (R Development Core Team, 2014).

\section{RESULTS}

\section{Grain size selection (Experiment 1)}

When comparing the total weight of the particles used in the original and the rebuilt cases, almost every individual used more grains during the building in all experimental conditions (mean weight of original cases: $0.222 \pm 0.068 \mathrm{~g}$; mean weight of rebuilt cases: $0.361 \pm 0.117 \mathrm{~g}$; Fig. 3). However, this difference decreased with increasing weight of the original cases as the original cases were heavier, the rebuilt ones were proportionally less heavy (slope $=0.780$, intercept $=0.180, p<0.005$, adjusted $\mathrm{R}^{2}=0.180$ ).

Original cases were composed of a mixture of $\mathrm{L}, \mathrm{M}$, and $\mathrm{S}$ grain sizes, although $\mathrm{M}$ was the preferred size in weight followed by $L$ and $S$ (Fig. 4a). Pairwise Wilcox tests between each size were significant (pairwise Wilcox tests: L-M $p=3.3 \mathrm{e}-10$, L-S $p=0.001$, M-S $p<0.001)$. When the proportion of particles in the original cases was compared with that of the rebuilt cases in the LMS experimental condition, we found no significant differences for $\mathrm{L}$ and $\mathrm{M}$ (pairwise Wilcoxon test: L-M $p=0.310$ ) (Fig. 4b). For both, the original and the rebuilt cases in the LMS experimental condition, the proportion of S was significantly lower than the other grain sizes used (pairwise Wilcoxon tests: Original: L-S $p=0.001, \mathrm{M}-\mathrm{S}$ $p=4.3 \mathrm{e}-15$; Rebuilt: L-S $p=0.024$, M-S $p=0.024$ ). When building, individuals needed more time to build the new case as the grain size decreased (Fig. 5); S being the experimental condition which required more time. In those experimental conditions where $\mathrm{S}$ was present in combination with $\mathrm{M}$ or $\mathrm{L}$, larvae also needed more time (pairwise Wilcoxon tests: LM-S $p=0.010$, LM-MS $p=0.022$, LM-LS $p=0.012$ ) (Fig. 5).

The amount of silk used for building cases in the different experimental conditions differed (Kruskal-Wallist test: chi-squared $=18.028$, 


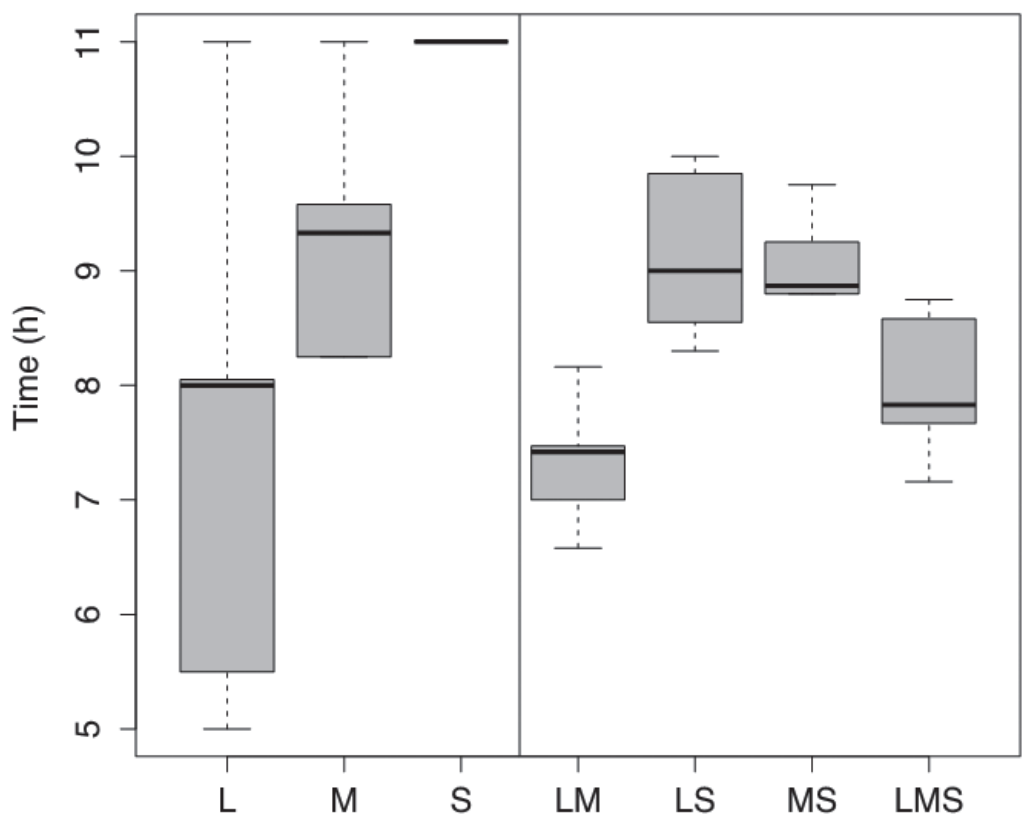

Figure 5. Duration of case building by $P$. latipennis larvae in the different combinations of grain sizes $(\mathrm{L}=\mathrm{large}, \mathrm{M}=$ medium, $\mathrm{S}=$ small, LM = large and medium, LS= large and small, MS = medium and small, and LMS = large, medium and small). The vertical line separates experimental conditions with single grain sizes from combination of grain sizes. Duración de la construcción del estuche de P. latipennis en diferentes combinaciones de tamaños de partículas ( $L=$ grande, $M=$ mediana, $S=$ pequeña, $L M=$ grande y mediana, $L S=$ grande y pequeña, $M S=$ mediana y pequeña, y LMS = grande, mediana y pequeña). La línea vertical separa las condiciones experimentales con tamaños de partículas únicos o combinaciones.

$p=0.006$ ), with $\mathrm{L}$ being the size that requires the highest amount of silk and S the lowest (Fig. 6a). When relating the time spent to build with the amount of silk used in the rebuilt cases, a significant and negative relationship was found (slope $=-0.409$, intercept $=9.647, p<0.01$, adjusted $\mathrm{R}^{2}=0.168$; Fig. 6b): individuals that needed less time (i.e., those in the $\mathrm{L}$ experimental condition followed by LM) spent more silk when building, whereas individuals that needed more time to build (i.e., those in the $\mathrm{S}$ experimental condition) spent less silk.

\section{Case repairing (Experiment 2)}

Larvae built cases in both substrate types but more silk was significantly used when building on the unfamiliar substrate (Kruskal-Wallis test: chi-squared=8.058, $p=0.004$; Fig. 7a). Larvae partially repaired their cases but still kept a significant percentage of unfamiliar grains at the end of the experiment (pairwise Wilcoxon test: $\mathrm{w}=218$, $p<0.001$; Fig. 7b). However, the amount of silk used after the repairing decreased in comparison to the used with the unfamiliar substrate but no significant differences were found (KruskalWallis test: chi-squared=3.25, $p<0.071$; Fig. 7a).

\section{DISCUSSION}

In agreement with our first hypothesis there was a trade-off between two critical aspects of case reconstruction in $P$. latipennis: time and silk expenditure. Case building in Trichoptera can occur during the aquatic stage, after predation attempts, growth, and other forms of physical damage (Kwong et al., 2011). Moreover, it can influence both the survival and reproductive components of fitness. During case building, larva become more vulnerable to predation, thus survival selection should favour individuals that can build their cases quickly (Boyero et al., 

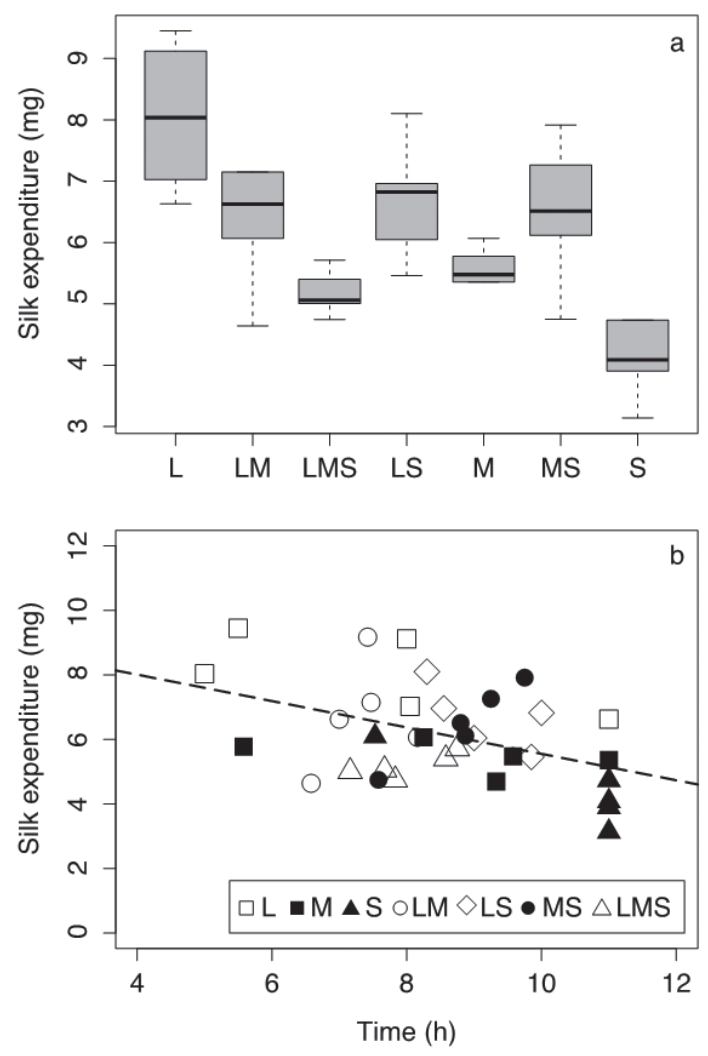

Figure 6. The amount of silk spent to build the new cases per each experimental condition (a) and the relationship between the time and the amount of silk used per individual to build (b). The dashed line is a linear model fit showing that there is a significant and negative relationship between both variables. ( $\mathrm{L}$ = large grain size, $\mathrm{M}=$ medium, $\mathrm{S}=$ small, $\mathrm{LM}=$ large and medium, LS= large and small, MS = medium and small, and LMS = large, medium and small). Cantidad de seda utilizada para construir los nuevos estuches en cada condición experimental (a) y la relación entre el tiempo y la cantidad de seda usada por individuo para la construcción (b). La línea discontínua es el ajuste lineal que muestra que hay una relación significativa y negativa entre las dos variables. ( $L=$ tamaño de partícula grande, $M=$ mediana, $S=$ pequeña, $L M=$ grande $y$ mediana, $L S=$ grande y pequeña, $M S=$ mediana y реqueña, $y$ LMS = grande, mediana y pequeña).

2006). However, fecundity selection may act against fast building if it consumes large amounts of nutrients detracting limited energy resources from reproduction (Wheeler, 1996; Stevens et al., 2000; McKie 2004, Jannot et al., 2007; Mondy et al., 2012). Our study shows that grain-size selection during building is a behavioural trait that mediates a trade-off. However, the results of our two experiments also show that survival is prior- itized even though it requires higher cost of silk expenditure. In agreement with this, Houghton \& Stewart (1998) also found that an emergency-case is immediately produced when insects are experimentally deprived of their case.

Evolutionary trade-offs among traits are common in nature despite there have been several difficulties to demonstrate them (e.g. van Noordwijk \& de Jong, 1986; Roff \& Fairbairn, 2007). Some examples of trade-offs include a wide variety of traits related to fecundity, survival and growth, such as age and size at maturity, reproductive investment, lifespan, aggregation behaviour, dispersal (e.g., Stearns, 1989; Gustafsson et al., 1994 Ots \& Horak, 1996; Hughes et al., 2003; Blomquist, 2009). Although less studied than terrestrial organisms, freshwater fish, amphibians, macroinvertebrates, macrophytes, and riparian plants also exhibit trade-offs (e.g., fish: Teletchea \& Fontaine, 2010; Morrongiello et al., 2012; amphibians: Skelly, 1995; Mueller et al., 2012; macroinvertebrates: Lewis, 2001; De Block \& Stoks, 2005; macrophytes and riparian plants: Barrat-Segretain, 2001; Karrenberg et al., 2002). Concerning Trichoptera, Okano \& Kikuchi (2009) described a possible trade-off in Goera japonica between the costs of material selection and silk secretion for case construction by caddisfly larvae; saving energy by secreting less silk on smoother particles allows more energy to be spent on selecting the preferred smoother particles or on other activities. A trade-off between larval and adult stages was also described by Stevens et al. (2000). In this case, an increased larval expenditure of silk by fifth-instar larvae of Glyphotaelius pellucidus and Odontocerum albicorne was associated to a reduced size of some parts of the adult body.

In agreement with other studies, $P$. latipennis can switch to other grain sizes when the preferred size is not available (Hanna, 1961, Tolkamp, 1980), indicating also that larval survival is prioritized. However, our second experiment shows that river substrate is preferred over the unfamiliar one because larvae replaced unfamiliar grains (i.e., smoother and with more silk requirements) by river ones (i.e., coarser and with less silk requirements), even if the overall silk expenditure increased. This was not the case of G. japonica, 

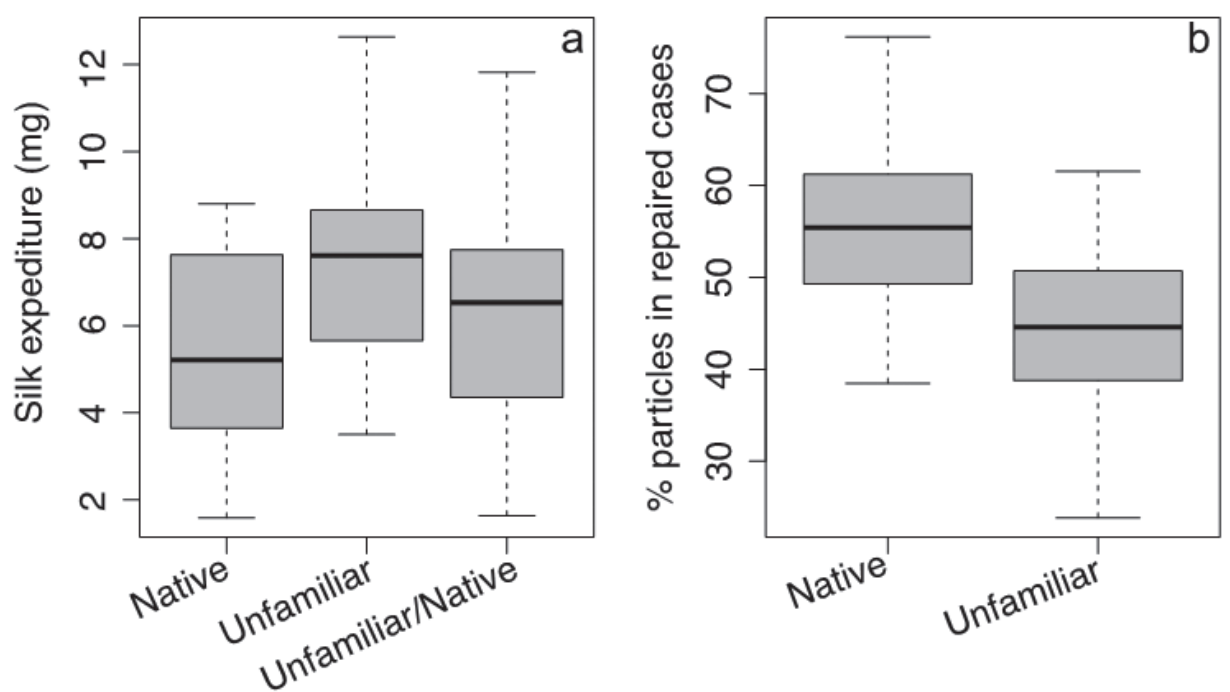

Figure 7. Amount of silk used when building over a native and unfamiliar substrate and after the repair (i.e., individuals that built cases first over a unfamiliar substrate and then over a native substrate) (a) and the weight percentage of native and unfamiliar particles at the end of the repairing experiment (i.e., only those individuals that built cases first over a unfamiliar substrate and then over a native substrate are considered here) (b). Cantidad de seda utilizada durante la construcción del estuche con sustrato nativo y no habitual, y después de la reparación (i.e., individuos que primero construyeron estuches con sustrato no habitual y después con sustrato nativo) (a) y proporción en peso de partículas nativas y no habituales al final del experimento de reparación (i.e., se han considerado solo aquellos individuos que construyeron primero estuches con sustrato no habitual y después con sustrato nativo) (b).

which selected smoother particles because less silk was used than when selecting rough particles (Okano \& Kikuchi, 2009; Okano et al., 2010), indicating that repairing behaviour can differ among species.

Case building involves an extra cost for individuals (Kwong et al., 2011) than can be highly significant (Otto, 1974) and have consequences on adult traits (Stevens et al., 1999, 2000). In P. latipennis, despite the replacement of unfamiliar by native grains increased the overall amount of silk used, the final cases had similar amount of silk to the original ones. Having a case most similar as possible to the original one is preferred despite the fact that it requires more efforts and a larger amount of the total silk produced. Despite unfamiliar grains being smoother, the benefits of having a case with native grains could be related to the lower waviness of native grains or phylogenetic aspects (Stuart \& Currie, 2001).

Although building requires high energetic costs which can have significant consequences on adult reproductive traits (Stevens et al., 1999; Stevens et al., 2000; Venner et al., 2003; McKie,
2004; Hansell, 2005), building cases to increase larval survival is preferred in P. latipennis. This indicates that native selection will favour larval survival over adult fecundity traits under the trade-off framework.

\section{ACKNOWLEDGMENTS}

We would like to sincerely thank Beatriz Willink for her valuable comments on earlier versions of this manuscript and Pau Fortuño for his help preparing the aquarium and his technical support throughout the experiment development. We also thank the two anonymous reviewers for their detailed and meaningful comments that helped to improve this paper.

\section{REFERENCES}

BARRAT-SEGREATIN, M.H. 2001. Biomass allocation in three macrophyte species in relation to the disturbance level of their habitat. Freshwater Biology, 46: 935-945. DOI: 10.1046/j.1365-2427.2001.00728.x

BLOMQUIST, G.E. 2009. Trade-off between 
age of first reproduction and survival in a female primate. Biology Letters, 5(3): 339-342. DOI: 10.1098/rsbl.2009.0009

BOGGS, C.L. 1981. Nutritional and life-history determinants of resource allocation in holometabolous insects. American Naturalist, 117: 692-709. DOI: 10.1086/283753

BOYERO, L., P.A. RINCÓN \& J. BOSCH. 2006. Case selection by a limnephilid caddisfly [Potamophylax latipennis (Curtis)] in response to different predators. Behavioral Ecology and Sociobiology, 59: 364-372. DOI: 10.1007/s00265-005-0059-y

BUCHELI, S., J.F. LANDRY \& J. WENZEL. 2002. Larval case architecture and implications of host-plant associations for North American Coleophora (Lepidoptera; Coleophoridae). Cladistics, 18: 71-93. DOI: 10.1111/j.1096-0031.2002.tb00141.x

CHABOO, C.S., C.G. BROWN \& D.J. FUNK. 2008. Faecal case architecture in the gibbosus species group of Neochlamisus Karren, 1972 (Coleoptera: Chrysomelidae: Cryptocephalinae: Chlamisini). Zoological Journal of the Linnean Society, 152: 315-351. DOI: 10.1111/ j.1096-3642.2007.00343.x

DE BLOCK, M. \& R. STOKS, R., 2005. Pond drying and hatching date shape the tradeoff between age and size at emergence in a damselfly. Oikos, 108: 485-494. DOI: 10.1111/j. 0030-1299.2005.13471.x

DUDGEON, D. 1990. Functional significance of selection of particles and their use by aquatic animals in the construction of external structures. In: The Biology of Particles in Aquatic Systems. R. S. Wotton (ed.): 263-288. CRC Press, Boca Raton. Florida. USA. DOI: 10.1111/j.0030-1299.2005.13471.x

GAINO, E., F. CIANFICCONI, M. REBORA, \& B. TODINI. 2002. Case-building of some Trichoptera larvae in experimental conditions: Selectivity for calcareous and siliceous grains. Italian Journal of Zoology, 69: 141-145.

GONZÁLEZ, M.A., L.S.W. TERRA, D. GARCÍA DE JALÓN \& F. COBO. 1992. Lista faunística y bibliográfica de los Tricópteros (Trichoptera) de la Península Ibérica e Islas Baleares. Asociación Española de Limnología, Madrid. Spain.
GORTER, F.J. 1931. Köcherbauversuche an Trichopterenlarven. Zeitschrift für Morphologie und Ökologie der Tiere, 20: 443-532.

GRAF, W., J. MURPHY, J. DAHL, C. ZAMORA-MUÑOZ \& M.J. LÓPEZ RODRÍGUEZ. 2008. Distribution and Ecological Preferences of European Freshwater Organisms: Trichoptera. Pensoft Publishers. Sofia. Bulgaria.

GUPTA, T.S. \& K.W. STEWART. 2000. Life history and case building behavior of Molanna tryphena (Trichoptera: Molannidae) in two east Texas spring-fed streams. Annals of the Entomological Society of America, 93: 65-74. DOI: 10.1603/0013-8746(2000)093[0065:LHACBB]2.0.CO;2

GUSTAFSSON, L., D. NORDLING, M.S. ANDERSSON, B.C SHELDON \& A. QVARNSTROM. 1994. Infectious diseases, reproductive effort and the cost of reproduction in birds. Philosophical Transactions of the Royal Society of London B, Biological Sciences, 346: 323-331. DOI: 10.1098/rstb. 1994.0149

HANNA, H.H. 1961. Selection of materials for case-building by larvae of caddis flies (Trichoptera). Proceedings of the Royal Entomological Society of London (series A), 36: 37-47. DOI: 10.1111/j.1365-3032.1961. tb00257.x

HANSELL, M.H. 1974. The house building of caddis larvae: a source of projects for schools. Journal of Biological Education, 8: 88-98. DOI: 10.1080/00219266.1974.9653920

HANSELL, M.H. 2005. Animal Architecture. Oxford University Press, Oxford. UK.

HOUGHTON, D.C. \& K.W. STEWART. 1998. Life history and case-building behavior of Culoptila cantha (Trichoptera: Glossosomatidae) in the Brazos River, Texas. Annals of the Entomological Society of America, 91: 59-70. DOI: 10.1093/aesa/91.1.59

HYNES, H.B.N. 1970. The ecology of running waters. Liverpool University Press, Liverpool. United Kingdom.

HUGHES, C.L., J.K. HILL \& C. DYTHAM. 2003. Evolutionary trade-offs between reproduction and dispersal in populations at expanding range boundaries. Proceedings of the Royal Society B, Biological Sciences 
(Suppl.), 270: S147-S150. DOI: 10.1098/rsbl. 2003.0049

JANNOT, J.E., E. BRUNEAU \& S.A. WISSINGER. 2007. Effects of larval energetic resources on life history and adult allocation patterns in a caddisfly (Trichoptera: Phryganeidae). Ecological Entomology, 32: 376-383. DOI: 10.1111/j.1365-2311.2007.00876.x

KARRENBERG, S., P. J. EDWARDS \& J. KOLLMANN. 2002. The life history of Salicaceae living in the active zone of floodplains. Freshwater Biology, 47: 733-748. DOI: 10.1046/j.1365-2427.2002.00894.x

KWONG, L., P.K. MENDEZ \& V.H. RESH. 2011. Case-repair in three genera of caddisflies (Trichoptera). Zoosymposia, 5: 269-278. DOI: 10.11646/zoosymposia.5.1.20

LEWIS, D.B. 2001. Trade-offs between growth and survival: responses of freshwater snails to predacious crayfish. Ecology, 82(3): 758-765. DOI: $10.1111 / j .1365-2656.2006 .01137 . x$

MCKIE, B.G. 2004. Disturbance and investment: developmental responses of tropical lotic midges to repeated tube destruction in the juvenile stages. Ecological Entomology, 29: 457-466. DOI: 10.1111/j.0307-6946.2004. 00622.x

MENDEZ, P. \& V.H. RESH. 2008. Life history of Neophylax rickeri (Trichoptera: Uenoidae) in two Northern California Streams. Entomological Society of America, 101: 573-584. DOI: $\quad 10.1603 / 0013-8746(2008) 101[573: L-$ HOTNR]2.0.CO;2

MONDY, N., B. REY \& Y. VOITURON. 2012. The proximal costs of case construction in caddisflies: antioxidant and life history responses. The Journal of Experimental Biology, 215: 3453-3458. DOI: 10.1242/jeb. 071142

MORRONGIELLO, J.R., N.R. BOND, D.A. CROOK \& B.B.M. WONG (2012). Spatial variation in eff size and eff number reflects trade-offs and bet-hedging in a freshwater fish. Journal of Animal Ecology, 81: 806-817. DOI: $10.1111 / \mathrm{j} .1365-2656.2012 .01961 . x$

MUELLER, C.A., S. AUGUSTINE, S.A.L.M. KOOIJMAN, M.R. KEARNEY \& R.S. SEYMOUR. 2012. The trade-off between maturation and growth during accelerated develop- ment in frogs. Comparative Biochemistry and Physiology, Part A: Molecular \& Integrative Physiology, 163(1): 95-102. DOI: 10.1016/j. cbpa.2012.05.190

NEPOMNYASHCHIKH, V.A. 1992. The control of selection of particles for case building by larvae of Chaetopteryx villosa Fabr. (Trichoptera: Limnephilidae), Larvae. In: Proc. 7th international symposium on Trichoptera. C. Otto (ed.): 263-265. Backhuys Pub, Umea. Sweden.

NEWBURY, R.W. \& M.N. GABOURY. 1993. Stream Analysis and Fish Habitat Design. Newbury Hydraulics. Gibsons, British Columbia. Canada.

NISLOW, K.H. \& M.C.JR. MOLLES. 1993. The influence of larval case design on vulnerability of Limnephilus frijole (Trichoptera) to predation. Freshwater Biology, 29: 411-417. DOI: 10.1111/j.1365-2427.1993.tb00775.x

NORWOOD, J.C. \& K.W. STEWART. 2002. Life history and case-building behavior of Phylloicus ornatus (Trichoptera: Calamoceratidae) in two spring-fed streams in Texas. Annals of the Entomological Society of America, 95: 44-56. DOI: 10.1603/0013-8746 (2002)095[0044:LHACBB]2.0.CO;2

OKANO, J.I. \& E. KIKUCHI. 2009. The effects of particle surface texture on silk secretion by the caddisfly Goera japonica during case construction. Animal Behaviour, 77(3): 595-602. DOI: 10.1016/j.anbehav.2008.10. 027

OKANO, J. I., E. KIKUCHI \& O. SASAKI. 2010. The role of particle surface texture on case material selection and silk lining in caddis flies. Behavioral Ecology, 21(4): 826-835. DOI: 10.1093/beheco/arq066

OKANO, J. I., E. KIKUCHI \& O. SASAKI. 2012. Mineralogical composition of sediment determines the preference for smooth particles by caddisfly larvae during case construction. Ecological Entomology, 37(5): 426-434. DOI: $10.1111 / \mathrm{j} .1365-2311.2012 .01382 . \mathrm{x}$

OTS, I. \& P. HORAK. 1996. Great tits, Parus major, trade health for reproduction. Proceedings of the Royal Society of London B, Biological Sciences, 263: 1443-1447. DOI: 10.1098/rspb.1996.0210 
OTTO, C. 1974. Growth and energetic in larval population of Potamophylax cingulatus (Steph.) (Trichoptera) in a South Swedish stream. Journal of Animal Ecology, 43: 339-361. DOI: 10.2307/3369

OTTO, C. 1982. Habitat, size and distribution of Scandinavian limnephilid caddisflies. Oikos, 38: 355-360. DOI: $10.2307 / 3544676$

OTTO, C. \& A. JOHANSSON. 1995. Why do some caddis larvae in running waters construct heavy, bulky cases? Animal Behaviour, 49: 473-478. DOI: 10.1006/anbe.1995. 0061

OTTO, C \& B. S. SVENSSON. 1980. The significance of case material selection for the survival of caddis larvae. Journal of Animal Ecology, 49: 855-865. DOI: 10.2307/4231

R DEVELOPMENT CORE TEAM. 2014. R: A language and environment for statistical computing. R Foundation for Statistical Computing, Vienna, Austria. URL http://www.R-project.org.

ROFF D.A. \& D.J. FAIRBAIRN. 2007. The evolution of trade-offs: where are we? Journal of Evolutionary Biology, 20: 433-447. DOI: 10.1111/j.1420-9101.2006.01255.x

SKELLY, D.K. 1995. A behavioural trade-off and its consequence for the distribution of Pseudacris treefrog larvae. Ecology, 76(1): 150-164. DOI: 10.2307/1940638

STATZNER, B., S. MÉLRIGOUX \& $\mathrm{M}$. LEICHTFRIED. 2005. Mineral grains in caddisfly pupal cases and streambed sediments: resource use and its limitation through conflicting resource requirements. Limnology and Oceanography, 50: 713-721. DOI: 10.4319/lo.2005.50.2.0713

STEARNS, S.C. 1989. Trade-offs in life-history evolution. Functional Ecology, 3: 259-268. DOI: $10.2307 / 2389364$

STEVENS, D.J., M.H. HANSELL, J.A. FREEL \& P. MONAGHAN. 1999. Developmental trade-offs in caddis flies: Increased investment in larval defense alters adult resource allocation. Proceedings of the Royal Society of London (Series B), 266: 1049-1054. DOI: 10.1098/rspb.1999.0742

STEVENS, D.J., M.H. HANSELL \& P. MONAGHAN. 2000. Developmental trade-offs and life histories: strategic alloca- tion of resources in caddis flies. Proceedings of the Royal Society of London (Series B), 267: 1511-1515. DOI: 10.1098/rspb.2000.1172

STUART, A.E. \& D.C. CURRIE. 2001. Using caddisfly (Trichoptera) case-building behaviour in higher level phylogeny reconstruction. Canadian Journal of Zoology, 79: 1842-1854. DOI: 10.1139/z01-145

TELETCHEA, F. \& P. FONTAINE. 2010. Comparison of early life-stage strategies in temperate freshwater fish species: trade-offs are directed towards first feeing of larvae in spring and early summer. Journal of Fish Biology, 77: 257-278. DOI: 10.1111/j.10958649.2010.02689.x

TOLKAMP, H.H. 1980. Organism-substrate relationships in lowland streams. Agricultural Research Reports, Wageningen. The Netherlands.

VAN NOORDWIJK, A.J. \& G. DE JONG. 1986. Acquisition and allocation resources; their influence on variation in life history tactics. American Naturalist, 128(1): 137-142. DOI: 10.1086/284547

VENNER, S., M.C. BEL-VENNER, A. PASQUET \& R. LEBORGNE. 2003. Body-mass-dependent cost of web-building behavior in an orb weaving spider, Zygiella x-notata. Naturwissenschaften, 90: 269-272. DOI: 10.1006/anbe.1999.1327

VIEIRA-LANERO, R. 2000. Las larvas de los Tricópteros de Galicia (Insecta; Trichoptera). Ph.D. Thesis. University of Santiago de Compostela, Spain.

WHEELER, D. 1996. The role of nourishment in oogenesis. Annual Review of Entomology, 41: 407-431. DOI: 10.1146/annurev.en.41. 010196.002203

WIGGINS, G.B. 1996. Larvae of the North American caddisfly genera (Trichoptera). University of Toronto Press, Toronto. Canada.

WIGGINS, G.B. 2004. Caddisflies: The Underwater Architects. University of Toronto Press, Toronto. Canada.

WILLIAMS, D.D. 1987. The Ecology of Temporary Waters. Croom Helm, London. UK.

WISSINGER, S.A., C. ELDERMIRE \& J.C. WHISSEL. 2004. The role of larval cases in reducing aggression and cannibalism among 
caddisflies in temporary wetlands. Wetlands, 24: 777-783. DOI: 10.1672/0277-5212(2004) 024[0777:TROLCI]2.0.CO;2

WISSINGER, S.A., J.C. WHISSEL, C. ELDERMIRE \& W.S. BROWN. 2006. Predator defense along a permanence gradient: roles of case structure, behavior, and developmental phenology in caddisflies. Oecologia, 147:
667-678. DOI: 10.1007/s00442-005-0303-1 ZAMORA-MUÑOZ, C. \& B. SVENSSON. 1996. Survival of caddis larvae in relation to their case material in a group of temporary and permanent pools. Freshwater Biology, 36: 23-3. DOI: 10.1046/j.1365-2427.1996. 00057.x 